\title{
Living with high concentrations of urea: They can!
}

\author{
Francesca Trischitta ${ }^{*}$, Caterina Faggio, Agata Torre \\ Dipartimento di Scienze della vita “M. Malpighi”, Università di Messina, Viale F. Stagno d’Alcontres, Messina, Italy; \\ *Corresponding Author: ftrischi@unime.it
}

Received 26 October 2011; revised 3 December 2011; accepted 17 December 2011

\begin{abstract}
Marine elasmobranchs maintain their body fluid isoosmotic or slightly hyperosmotic to the external medium by the retention of large urea concentrations. This review focuses on the strategies adopted by these fishes to maintain a large outwardly direct concentration gradient of this osmolyte minimizing the loss across the main interfaces between body fluid and the external medium such as the gills, the kidney and the rectal gland, thus reducing the cost of making urea. The high plasma osmolarity, mainly maintained by urea retention, is a challenge to volume homeostasis when fish move from seawater to water with a low salinity, since the high water permeability of branchial epithelium would cause a net flux of water into the animal. Since the renal regulation of urea retention in habitat with different salinities is crucial for the osmotic homeostasis of these species, the regulation of the activity and/or the expression of urea transporters in renal tubules will be also discussed. In addition attention will be paid on the ureamethylamine system involved in maintaining the stability and functioning of many proteins since it is known that the high urea concentration found in marine elasmobranch fish, similar only to that found in mammalian kidney, has a destabilizing effect on many macromolecules and inhibits functions such as ligand binding.
\end{abstract}

Keywords: Elasmobranch; Urea; TMA; Gills; Kidney; Rectal Gland

\section{INTRODUCTION}

It is known that the strategy adopted by the elasmobranch fish to live in the seawater, having an electrolyte content higher than plasma and tissue, is different from the strategy adopted by marine teleosts. They avoid dehydration and maintain plasma osmolarity lower than the surrounding medium by drinking sea water and absorb- ing $\mathrm{NaCl}$ and hence water by the intestinal fluid desalinated at esophageal level while excess of $\mathrm{NaCl}$ is excreted across the gills. Elasmobranch fish achieve plasma ionic homeostasis and maintain a plasma osmolarity equal or slightly higher than sea water by actively excreting excess $\mathrm{NaCl}$ by rectal gland (Figure 1) and retaining large amounts of urea. Many works have been performed to study the osmoregulatory strategies adopted by elasmobranch fish and the results obtained have been reviewed by many authors [1-8].

This review will focus on studies performed in order to answer to the questions raised by the strategy of retaining urea, such as:

1) Which are the mechanisms allowing urea retention?

2) Since urea retention in fresh water is maladaptive, in which way does the whole picture of urea system change in euryhaline elasmobranchs?

3) How the destabilizing effects of urea are counteracted?

\section{WHICH ARE THE MECHANISMS ALLOWING UREA RETENTION?}

In most elasmobranch urea is the end product of ni-

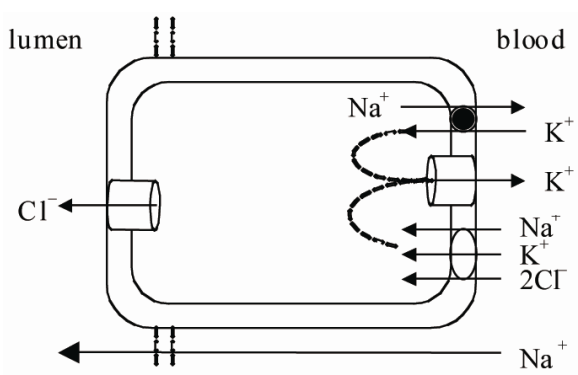

Figure 1. $\mathrm{NaCl}$ excretion in a rectal gland cell. $\mathrm{Cl}^{-}$diffuse across the apical membrane into the lumen of rectal gland driven by its electrochemical gradient. The $\mathrm{Na}^{+} \mathrm{K}^{+}$ATPase provides the driving force for the operation of the basolateral $\mathrm{Na}^{+}-\mathrm{K}^{+}-2 \mathrm{Cl}^{-}$cotransport and hence for the active accumulation of $\mathrm{Cl}^{-}$. The mucosal negative transepithelial potential generated by $\mathrm{Cl}^{-}$secretion favours $\mathrm{Na}^{+}$efflux through the cation selective tight junction (see ref 3). 
trogen metabolism and it is mainly produced in the liver in the ornithine-urea cycle through carbamoylphosphate synthetase III [9-11]. Marine elasmobranchs retain large amount of urea in order to maintain body fluids isoosmotic or slightly iperosmotic to the surrounding seawater $[12,13]$. They accumulate urea to concentrations as high as 350 - $500 \mathrm{mM}$ [14-16]. In order to maintain a large outwardly direct concentration gradient they must minimize the loss across the main interfaces between body fluid and the external medium such as the gills, the kidney and the rectal gland, thus reducing the cost of making urea.

Noteworthy a role of gut in urea conservation has been recently suggested, but the mechanisms involved are not well known [11].

\subsection{Gills}

Fish gills have a large surface area and a short diffusion distance necessary to allow an efficient exchange of respiratory gases between the blood and the extracellular medium. This arrangement is also responsible of a large diffusive movement of solute and water between the organism and sea-water. In the elasmobranchs the maintenance of high plasma concentration of urea implies that the loss of this osmolyte across the gills must be low. Indeed the pioneering work of Boylan [17] suggested that the gill epithelium of Squalus acanthias is exceptionally tight to urea. In order to explain this impermeability Boylan [17] and Part et al. [18] evaluated two hypotheses:

1) gill epithelium (particularly the apical membrane of the cells) is impermeable to urea due to the peculiar composition of the membrane, since it had been showed that in artificial membranes a selective impermeability to urea can be obtained by modifying lipid composition, i.e. by increasing sphingomielin content [19].

2) Gill epithelium forms an intermediary compartment between blood and the external medium in which the intracellular urea concentration is kept lower than in the body fluid by a basolateral urea transporter that actively transports into the blood urea that entries the cell from the blood or that is synthesized in the cell. In such a way the diffusive loss across the apical membrane into the sea-water would be reduced.

Part et al. [18], by a study with a perfused gill preparation from dogfish, concluded that the apical membrane is extremely tight to urea, having an urea permeability coefficient of $3 \times 2 \times 10^{-8} \mathrm{~cm} \cdot \mathrm{sec}^{-1}$ that is lower that one of teleost epithelium $\left(2 \times 6 \times 10^{-6} \mathrm{~cm} \cdot \mathrm{sec}^{-1}\right)$. A low urea permeability of apical membrane was suggested also by Hill et al. [20] but it was concluded that it cannot account for low urea loss measured in elasmobranch.

Part et al. [18] showed that the overall impermeability of gill epithelium is also due to a putative back-transport of urea in the basolateral membrane, since phloretin, a non competitive inhibitor of urea transport, increases urea efflux across the gills. Following studies confirmed the presence of urea transporters in elasmobranch gills. The low-stringency Northern analysis revealed that an homologue of the renal urea transport is present in the gill of S. acanthias [21]. Analyses of urea uptake by vesicles prepared from enriched basolateral membrane of S. acanthias [22], showing a saturation kinetics at low urea concentration, suggested the presence of a carriermediated urea transport having high affinity for urea, it is a $\mathrm{Na}^{+}$-coupled secondary transport functioning in an antiport function (Figure 2). The antiporter is responsible of a significant metabolic saving since the metabolic cost of synthesize one urea molecule (5 ATP equivalents) is much higher than the cost for transporting urea to the blood via a $\mathrm{Na}^{+}-\mathrm{K}^{+}$dependent urea transport (about 0.2 ATP equivalent for molecule of urea returned to the blood). However, Fines et al. [22] suggested that the low urea permeability of spiny dogfish gills is accomplished not only by the active transport of the osmolyte but also by an unusual composition of basolateral membrane that presents an elevated cholesterol to phospholipids molar ratio.

\subsection{Rectal Gland}

Another striking feature of elasmobranch is the low urea permeability of the rectal gland. This organ, having the important role to excrete excess $\mathrm{NaCl}$ and water, secretes a fluid isotonic with plasma. This implies that water follows the diffusive flux of the electrolytes and hence the permeability of the rectal gland must be high.

Studies performed with liposomes having different lipid composition showed a parallelism between permeability to water and to urea $[20,23]$, so rectal gland would

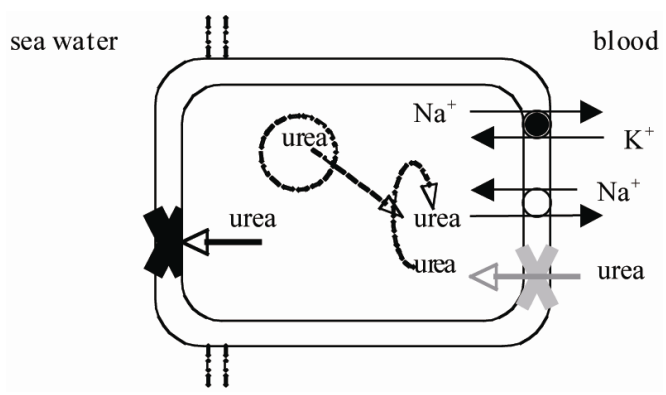

Figure 2. Possible mechanisms explaining the impermeability of gill epithelium of elasmobranch fish: a very low permeability of the apical membrane impeding the diffusive loss to seawater; a $\mathrm{Na}^{+}$-coupled secondary antiport that transports into the blood urea that is synthesized in the cell or that entries the cell from basolateral membrane having a low urea permeability (see text for the references). 
have an high urea permeability. This conclusion contrasts with the observation that the rectal gland fluid has a high level of $\mathrm{NaCl}$ (500 mM vs. $340-350 \mathrm{mM}$ in the plasma) but a low level of urea (18 mM vs. $330 \mathrm{mM}$ in the plasma) $[24,25]$ and strongly suggests a selective impermeability to urea of the rectal gland. Zeidel et al. [26] advanced two hypotheses to explain this unusual permeability characteristic of the rectal gland membranes:

1) The membranes possess specific water channel, aquaporins.

2) Apical or serosal membranes have a tight barrier to urea.

By using highly purified vesicles of apical or basolateral membranes of rectal gland of S. acanthias they measured their permeability to urea and to water. They showed that the water permeability was too low and the activation energy for water was too high to suppose the presence of aquaporins in both the apical and the serosal membranes and suggested that water crosses the membranes through the lipidic component. Comparison of water and urea permeability measured in rectal gland with that measured in artificial liposomes and in other biological membranes let the authors to conclude that the basolateral membranes have the role of selective barrier to urea in shark rectal gland. They suggested that this barrier could be due to the membrane lipidic components, as found in gill membranes [22], or to a protein component, as observed in the medullary thick ascending limb of Henle loop, where the paracellin-1, a member of claudin family, prevent the paracellular flux of water allowing the flux of $\mathrm{Mg}^{2+}$ and $\mathrm{Ca}^{2+}$ down their electrochemical gradient [27].

\subsection{Kidney}

Urea is freely filtered by the glomerulus but the urea excretion by the renal route is as low as $5 \%$ of the total body urea excretion [28]. Indeed it was calculated that $90 \%-96 \%$ of the filtered urea is reabsorbed in the renal tubules [29-31]. In order to explain the efficient urea reabsorption three different mechanisms, even if they were supported by poor experimental evidences, were initially proposed:

1) A carrier mediated passive process [12,32].

2) A passive reabsorption down a localized concentration gradient [33]. 35].

3) An active transport, possibly $\mathrm{Na}^{+}$-dependent $[34$,

More recently Smith and Wright [21] isolated a $2.2 \mathrm{~kb}$ cDNA from $S$. acanthias kidney encoding a 380 aminoacid protein with a $60 \%$ aminoacidic identity to the facilitated urea transport protein found in rat (UT-A2). They suggested that the shark urea transporter (Sh-UT), the first urea transporter isolated in a marine fish, consti- tutes a phylogenetic ancestral form of UT-A2 and that other urea transporter homologues may be present in elasmobranch species. A cDNA encoding a urea transporter homologue to Sh-UT was isolated from another dogfish species, Triakis scyllia [36]. It was abundantly expressed in the kidney but low levels were found in the brain and in the liver. Immunochemistry, using specific antibodies raised against the cloned UT, showed that the transport is localized in the collecting duct on both the apical and the serosal membranes of the epithelial cells. This localization supported the hypothesis that urea transport is performed by carrier mediated passive permeation, the other segments of the nephron acting as a countercurrent multiplier system that produces the driving force for facilitated diffusion of urea.

The peculiar arrangement of elasmobranch nephron (see Figure 3) leading to a countercurrent system was described by Lacy and Reale $[37,38]$ and by Hentschel $e t$ al [39]; it is typical of all marine elasmobranchs. The nephron consists of four loops beginning at renal corpuscle located between the dorsal bundle zone (where the tubule segments are tightly packed) and the ventral sinus zone (where the tubule segments are loosely packed and segregated from each other by large blood sinuses). The I loop is in the bundle zone, the tubule then extends in the sinus zone and turns back forming the II loop, from which the III loop originates; it descends in the sinus zone forming the IV loop. This last loop returning to the bundle zone joins the collecting ducts. They fuse to form a collecting tube. The loop I and III together with the distal tubule belonging to the same nephron together with a network of anastomosing capillaries form a bundle enclosed by connective tissue called "peritubular sheet”, an impermeable peritubular sheet. This unit forms the countercurrent system of the nephron of elasmobranch.

Two different urea transporters were identified in the ventral and in the dorsal zone of the little skate, Raja

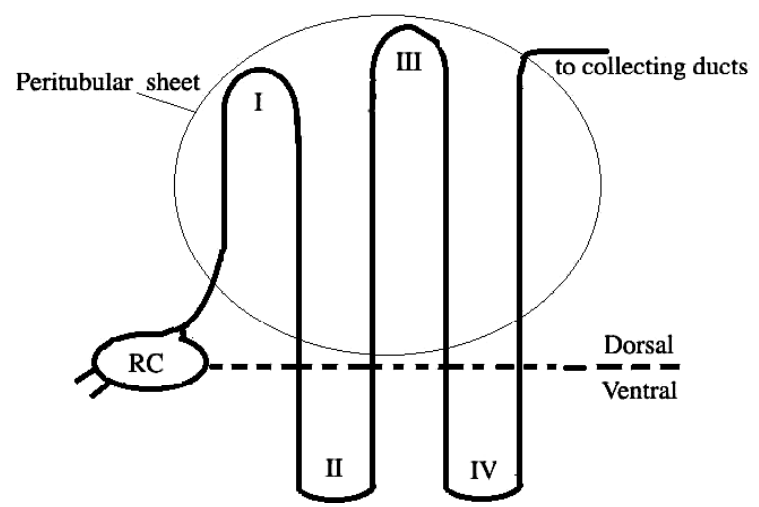

Figure 3. Schematic drawing of an elasmobranch nephron as described by Lacey and Reale [37]. RC = renal corpuscle; I, II, II and IV indicate the loop number. 
erinacea, by using brush border membrane vesicles from the two different sections of the kidney [40]. The authors showed that in the dorsal zone urea transport was not saturable, was sensitive to the non competitive inhibitors phloretin and $\mathrm{HgCl}_{2}$ and was significantly reduced in the presence of an urea analogue. By these results they suggested the presence of one or more facilitated urea transporters possibly coded by skUT (skate urea transporter) which expression had been already evidenced in both the dorsal and ventral section [41]. In the ventral tubules the presence of an additional transporter was proposed; it has the characteristic of a $\mathrm{Na}^{+}$-linked urea transporter, since it was stimulated by an inward $\mathrm{Na}^{+}$ gradient [40].

A close homologue of shUT, strUT-2, was cloned from the kidney of the Atlantic stingray, Dasyatis Sabina [42]. It was suggested that the presence of homologues in two species that have diverged in the elasmobranch evolution [43] speaks in favour of a conservation of this isoform. However in the Atlantic stingray another phloretin transporter, strUT-2, was also identified [44]. It has an high degree of sequence identity with shUT but has an unique extension of the hydrophilic $\mathrm{COOH}$-terminal region of about 51 aminoacids. In addition strUT-2 has a protein kinase regulatory site lacking in the shark urea transporter. The authors proposed that protein kinase may alter the function of the stingray transporter thus regulating urea reabsorption during the movement of the animal between habitats of different salinities. Indeed Atlantic stingray is an elasmobranch that, unlike the spiny dogfish, can move to habitats covering a large range of salinities.

\section{SINCE UREA RETENTION IN FRESH WATER IS MALADAPTIVE, IN WHICH WAY DOES THE WHOLE PICTURE OF UREA SYSTEM CHANGE IN EURYHALINE ELASMOBRANCH?}

Most elasmobranches live in seawater and are stenohaline while the stingrays of the genus Potamotrygon are the only elasmobranch permanently adapted to freshwater $[45,46]$. However a number of species are marginally euryhaline since they can enter in the brackish environment of river mouths [47] and a small number can move from seawater to freshwater, generally on a seasonal basis $[13,46,48,49]$.

The high plasma osmolarity, mainly maintained by urea retention, is a challenge to volume homeostasis when fish move from seawater to water with a low salinity, since the high water permeability of branchial epithelium would cause a net flux of water into the animal.

Since the kidney is the primary organ responsible of urea retention and euryhaline elasmobranchs remain ureotelic in environment with a low salinity [30,34,46,50-52] the renal regulation of urea retention in habitat with different salinities is crucial for the osmotic homeostasis of these species. This observation suggests that the activity and/or the expression of urea transporters in renal tubules have to be regulated. Indeed an increase in urea excretion relative to urea absorption in a diluted environment was described in the euryhaline skates [30,31].

Morgan et al. [41], using Northern analysis of mRNA from the kidney of the little skate Raja erinacea, revealed three bands of 3.1, 2.8, and $1.6 \mathrm{~kb}$ belonging to three isoforms of an urea transporter family. When the skates were exposed to diluted environment (50\% seawater) the levels of all three skUT transcripts were reduced by 1.8 - 3.5 folds. Since kidney osmolality and urea concentration decreased while water content increased, the authors suggested that the downregulation of skUT plays an important role in lowering tissue urea levels in response to the osmolality of the external medium.

A recent study of Yamaguchi et al. [53], by using semiquantitative fluorescent immunochemistry and realtime PCR, examined the localization and the mRNA levels of UT transporters in the in the collecting duct of the kidney of groups of T. scyllium held at different salinities. It was suggested that the transfer of this fish to a low salinity did not change the expression of UTs, as observed in $R$. erinacea [41], but modified the cellular distribution of the transporters. It was found that in the control T. scyllium (100\% seawater) UTs localized in both the apical and the basolateral membranes, with an higher expression in the apical membrane. In fish transferred to a diluted medium (30\% seawater) the immunoreactivity significantly decreased but the most pronounced change was in the apical membrane where the immunoreactivity almost disappeared, while a less pronounced immunoreactivity reduction was detected in the cytoplasm and in the serosal membrane. On the return to full seawater the apical distribution recovered its initial level (Figure 4).

These observations led the authors to conclude that UT distribution is regulated by its production and degrada-

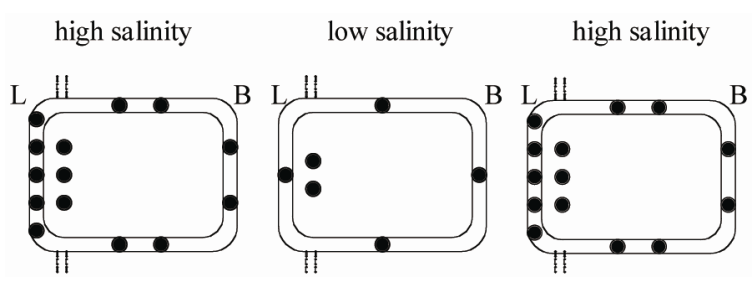

Figure 4. Redistribution of UT transporters (filled circles) in a cell lining the collecting duct of $T$. scyllum adapted to different salinities. In fish transferred to a diluted medium they significantly decrease but the most pronounced change is in the apical membrane. On the return to full seawater the distribution recovers its initial level (see text for the references). $\mathrm{L}=$ lumen; $\mathrm{B}=$ blood (see ref 53). 
tion as well as by trafficking between apical membrane and cytoplasm and suggested that the abundance of UT in the apical membrane functions as rate limiting factor for urea reabsorption; this trafficking should be controlled to regulate urea reabsorption. It was suggested that vasotocin can act as possible regulator in T. scyllum, similarly to vasopressin in mammals [54,55]. This hypothesis was based on two observations:

1) Plasma levels of vasotocin increase following transfer to concentrated seawater and decrease following transfer to dilute seawater $[53,56]$.

2) Plasma levels of the hormone correlate with the abundance of UTs in the luminal membrane and with urea plasma levels $[53,56]$.

However it is also possible that plasma and tissue levels of urea change as a consequence of a change of hepatic urea production. A decrease of urea production during the acclimation to fresh water was suggested for the little skate $R$. erinacea [30] for the dogfish Scyliorhinus canicula [57] and for the bullshark, Carcharinus leucas [58,59]. Tam et al. [58] showed that the acclimation of the freshwater stingray Himantura signifer to diluted seawater led to an increase of urea synthesis due to an upregulation of the enzymes of the ornithine-urea cycle.

The ability to modify urea production is different in the various elasmobranch species and it is probably related to their ability to survive in habitats with different salinities. $H$. signifer that is a species that can travel along the river and hence may experience brackish water maintains the ability to synthesize urea and has a reduced capacity to retain urea [58]. The stenohaline fresh-water rays Potamotrygon spp, that permanently dwell in fresh water, being confined in the Amazonian river basin away from ocean for million years $[60,61]$ are ammoniotelic and are not able to produce urea neither to counteract an experimental salinity stress $[45,62,63]$ nor as strategy to detoxify ammonia. In was observed that Potamotrygon motoro is not able to upregulated urea synthesis via the ornithine-urea cycle when exposed to environmental ammonia [64].

\section{HOW THE DESTABILIZING EFFECTS OF UREA ARE COUNTERACTED?}

It is known that the high urea concentration found in marine elasmobranch fish, similar only to that found in mammalian kidney [65], has a destabilizing effect on many macromolecules. In order to explain the mechanisms responsible of the chemical denaturation of urea two mechanisms have been proposed: the indirect and the direct mechanism. According to the indirect mechanism urea denatures protein by destroying water structure that in turn weakens the hydrophobic interaction responsible of the globular structure of the protein $[66,67]$. Ac- cording to the direct mechanism urea unfolds protein through a direct interaction mediated by either electrostatic interaction or van der Waals attraction [68-70].

The loss of structure influences enzyme kinetic properties [71,72], alters the melting point transition temperature of protein [73,74], inhibits functions as ligand binding [75] .

To counteract the destabilizing effect of urea, elasmobranchs accumulate methtylamine organic osmolytes [14, 71,76-78], since they are stabilizer of protein structures and activator of many functional properties of proteins [71,72]. Trimethyl amine oxide (TMAO) and betaine are the most effective [15] and the predominant methylamines found in the muscle of elasmobranches $[79,80]$. The level of TMAO, which primary role is that of an osmolyte, varies in the euryhaline species adapted to different salinities [76,81]. However in seawater elasmobranches TMAO is the major component while in the transition from euryhaline to freshwater elasmobranches betaine becomes the major methylamine [82].

A 2:1 concentration ratio of urea to these counteracting compounds is optimal for preserving proper protein function $[15,71,72]$.

In addition urea could increase the fluidity of membranes by a destructive effect on the hydrophobic core of the membrane or by indirect effects related to changes of integral membrane proteins. Barton et al. [4] showed that TMAO may act as counteracting solute in the red blood cell membrane of $R$. erinacea and suggested that the counteraction is at the level of integral proteins rather than on the membrane phospholipids.

Regarding the synthesis of the predominant methylamines it was suggested that betaine synthetic pathways are probably present in most or in all elasmobranches, like in the other vertebrates, since they play an important role in the catabolism of choline introduced by the food [83]. Betaine is synthesized from choline in metabolic pathways involving choline dehydrogenase (ChoDH) and aldehyde dehydrogenase (BADH). Measurable levels of these enzymes were found in various elasmobranch species [82].

In vertebrates TMAO derives from the oxidation of trimethylamine (TMA) through a reaction catalyzed by the trimethylamine oxidase (TMAox). This enzyme is sporadically present in elasmobranches [82,84-86] and when present its activity is high in the liver that should be the major site of TMAO synthesis [84,86,87]. It was suggested that the ability to maintain TMAO plasma concentration in species lacking of TMAox without an exogenous supply of TMAO for a long period depends on a release from muscle [85] as well as on a very low loss from the animal $[81,87,88]$. This can be due to a sustained reabsorption of the filtered TMAO $[30,89]$. In addition, in order to maintain elevated methylamine lev- 
els to counteract the destabilizing effect of urea in species lacking of TMAox, an activation of the enzyme involved in betaine synthesis during a period of exogenous supply of TMAO can occur [82].

\section{DISCUSSION}

In summary, studies hitherto performed suggest that, in order to maintain a large outwardly direct concentration gradient, both gills and rectal gland of elasmobranchs have an unusual permeability allowing the movement of water but not of urea. However in the gills an homologue of a renal urea transporter was also detected, suggesting a back-transport of the osmolyte in the basolateral membrane that contributes to avoid urea loss from the body. Various facilitated urea transporters have been identified in the elasmobranch renal tubules allowing the reabsorption of urea freely filtered by the glomerulus. The expression, the activity and/or the cellular localization of these transporters are probably regulated in the euryhaline species when they move to habitats with different salinities, in order to modify urea retention in response to osmotic challenges. The adaptation to different salinities involves also a variation of TMAO concentrations, the second osmolyte in elasmobranchs, that plays also the important role to counteract not only the destabilizing effect of urea on the structure and hence on the function of many proteins but also the urea effect on membrane fluidity.

However a multidisciplinary approach ranging from organism to molecular techniques is still necessary to complete the picture of the strategies adopted by different elasmobranch species for living with high urea concentrations. This approach will be necessary also to better understand how the urea levels are modulated to allow euryhaline species to live in habitats with different salinities.

\section{REFERENCES}

[1] Pang, P.K.T., Griffith, R.W. and Atz, J.W. (1977) Osmoregulation in elasmobranchs. American Zoologist, 17, 365-377.

[2] Shuttleworth, T.J. (1988) Salt and water balance-extrarenal mechanisms. In: Shuttleworth, T.J. Ed., Physiology of Elasmobranch Fishes, Springer-Verlag, Berlin, Heidelberg, 171-199. doi:10.1007/978-3-642-73336-9_6

[3] Karnaky, K. (1998) Osmotic and Ionic Regulation. In: Evans D.H. Ed., The Physiology of Fishes, CRC Press, Boca Raton, 157-176.

[4] Barton, K.N., Buhr, M.M. and Ballantyne, J.S. (1999) Effects of urea and trimethylamine N-oxide on fluidity of liposomes and membranes of an elasmobranch. American Journal of Physiology (Regulatory, Integrative and Comparative Physiology), 276, R397-R406.
[5] Hazon, N., Wells, A., Pillans, R.D., Good, J.P., Anderson, W.G. and Franklin, C.E. (2003) Urea based osmoregulation and endocrine control in elasmobranch fish with special reference to euryhalinity. Comparative Biochemistry and Physiology B, 136, 685-700. doi:10.1016/S1096-4959(03)00280-X

[6] Evans, D.H., Piermarini, P.M. and Choe, K.P. (2004) Homeostasis: Osmoregulation, $\mathrm{pH}$ regulation, and nitrogen excretion. In: Carrier, J.C., Musick, J.A. and Heithaus, M.R., Eds., Biology of Sharks and Their Relatives, CRC Press, Boca Raton, 247-268.

[7] Hammerschlag, N. (2006) Osmoregulation in elasmobranchs: A review for fish biologists, behaviourists and ecologists. Marine and Freshwater Behaviour and Physiology, 39, 209-228. doi:10.1080/10236240600815820

[8] Anderson, W.G., Taylor, J.R., Good, J.P., Hazon, N. and Grosell, M. (2007) Body fluid volume regulation in elasmobranch fish. Comparative Biochemistry and Physiology A, 148, 3-13. doi:10.1016/j.cbpa.2006.07.018

[9] Anderson, P.M. (1980) Glutamine- and N-acetylglutamatedependent carbamoyl phosphate synthetase in elasmobranchs. Science, 208, 291-293. doi:10.1126/science.6245445

[10] Anderson, P.M. (1991) Glutamine-dependent urea synthesis in elasmobranch fishes. Biochemistry and Cell Biology, 69, 317-319. doi:10.1139/091-049

[11] Anderson, W.G., Dasiewicz, P.J., Liban, S., Ryan, C., Taylor, J.R., Grosell, M. and Weihrauch, D. (2010) Gastro-intestinal handling of water and solutes in three species of elasmobranch fish, the white-spotted bamboo shark, Chiloscyllium plagiosum, little skate, Leucoraja erinacea and the clear nose skate Raja eglanteria. Comparative Biochemistry and Physiology A, 155, 493-502. doi:10.1016/j.cbpa.2009.09.020

[12] Smith, H.W. (1931) The absorption and excretion of water and salts by the elasmobranch fishes. II Marine elasmobranchs. American Journal of Physiology, 98, 296310.

[13] Thorson, T.B., Cowan, C.M. and Watson, D.E. (1973) Body fluid solutes of juveniles and adults of the euryhaline bull shark Carcharinus leucas from freshwater and saline environments. Physiologycal Zoology, 46, 29-42.

[14] Yancey, P.H., Clark, M.E., Hand, S.C., Bowlus, R.D. and Somero, G.N. (1982) Living with water stress: Evolution of osmolyte systems. Science, 217, 1214-1222. doi:10.1126/science.7112124

[15] Yancey, P.H. (1994) Compatible and counteracting solutes. In: Strange, K., Ed., Cellular and Molecular Physiology of Cell Volume Regulation, CRC Press, Boca Raton, 81-109.

[16] Ballantyne, J.S. (1997) Jaws: The inside story. The metabolism of elasmobranch fishes. Comparative Biochemistry and Physiology B, 118, 703-742. doi:10.1016/S0305-0491(97)00272-1

[17] Boylan, J.W. (1967) Gill permeability in Squalus acanthias. In: Gilbert, P.W., Mathewson, R.F., Rall, D.P. and Baltimore, M.D., Eds., Sharks, Skates and Rays, Johns Hopkins Press, 58-74. 
[18] Part, P., Wright, P.A. and Wood, C.M. (1998) Urea and water permeability in dogfish (Squalus acanthias) gills. Comparative Biochemistry and Physiology A, 119, 117123. doi:10.1016/S1095-6433(97)00400-5

[19] Lande, M.B., Donovan, J.M. and Zeidel, M.L. (1995) The relationship between membrane fluidity and permeabilities to water, solutes, ammonia, and protons. The Journal of General Physiology, 106, 67-84. doi:10.1085/jgp.106.1.67

[20] Hill, W.G., Mathai, J.C., Gensure, R.H., Zeidel, J.D., Apodaca, G., Saenz, J.P., Kinne-Saffran, E., Kinne, R. and Zeidel, M.L. ( 2004) Permeabilities of teleost and elasmobranch gill apical membranes: Evidence that lipid bilayers alone do not account for barrier function. American Journal of Physiology (Cell Physiology), 287, C235C242. doi:10.1152/ajpcell.00017.2004

[21] Smith, C.P. and Wright, P.A. (1999) Molecular characterization of an elasmobranch urea transporter. American Journal of Physiology (Regulatory, integrative and comparative physiology), 276, R622-R626.

[22] Fines, G.A., Ballantyne, J.S. and Wright, P.A. (2001) Active urea transport and an unusual basolateral membrane composition in the gills of a marine elasmobranch. American Journal of Physiology (Regulatory, Integrative and Comparative Physiology), 280, R16-R24.

[23] Mathai, J.C., Sprott, G.D. and Zeidel, M.L. (2001) Molecular mechanisms of water and solute transport across archaebacterial lipid membranes. Journal of Chemical Biology, 276, 27266-27271. doi:10.1074/jbc.M103265200

[24] Burger, J.W. and Hess, W.N. (1960) Function of the rectal gland in the spiny dogfish. Science, 131, 670-671. doi:10.1126/science.131.3401.670

[25] Burger, J.W. (1967). Problems in the electrolyte economy of the spiny dogfish, Squalus acanthias. In: Gilbert P.W., Mathewson R.F., Rall D.P. and Baltimore, M.D., Eds., Sharks, Skates and Rays, Johns Hopkins Press.

[26] Zeidel, J.D., Mathai, J.C., Campbell, J.D., Ruiz, W.G., Apodaca, G.L., Riordan, J. and Zeidel, M.L. (2005) Selective permeability barrier to urea in shark rectal gland. American Journal of Physiology (Renal Physiology), 289, F83-F89. doi:10.1152/ajprenal.00456.2004

[27] Simon, D.B., Lu, Y., Choate, K.A., Velazquez, H., Al-Sabban, E., Praga, M., Casari, G., Bettinelli, A., Colussi, G., Rodriguez-Soriano, J., McCredie, D., Milford, D., Sanjad, S. and Lifton, R.P. (1999) Paracellin-1, a renal tight junction protein required for paracellular $\mathrm{Mg}^{2+}$ reabsorption. Science, 285, 62-64. doi:10.1126/science.285.5424.103

[28] Wood, C.M., Part, P. and Wright, P.A. (1995) Ammonia and urea metabolism in relation to gill function and acidbase balance in a marine elasmobranch, the spiny dogfish (Squalus acanthias). The Journal of Experimental Biology, 198, 1545-1558.

[29] Clark, R.W. and Smith, H.W. (1932) Absorption and excretion of water and salts by the elasmobranch fishes. III. The use of xylose as a measure of the glomerular filtrate in Squalus acanthias. Journal of Cellular and Comparative Physiology, 1, 131-143. doi:10.1002/jcp.1030010202
[30] Goldstein, L. and Forster, R.P. (1971) Osmoregulation and urea metabolism in the little skate Raja erinacea. American Journal of Physiology, 220, 742-746.

[31] Payan, P., Goldstein, L. and Forster, R.P. (1973) Gills and kidneys in ureosmotic regulation in euryhaline skates. American Journal of Physiology, 224, 367-372.

[32] Smith, H.W. (1936) The retention and physiological role of urea in the elasmobranchii. Biological Reviews, 11, 49-52. doi:10.1111/j.1469-185X.1936.tb00497.x

[33] Boylan, J.W. (1972) A model for passive urea reabsorption in the elasmobranch kidney. Comparative Biochemistry and Physiology, 42, 27-30. doi:10.1016/0300-9629(72)90361-1

[34] Schmidt-Nielsen, B., Truniger, B. and Rabinowitz, L. (1972) Sodium-linked urea transport by the renal tubule of the spiny dogfish Squalus acanthias. Comparative Biochemistry and Physiology A, 42, 13-25. doi:10.1016/0300-9629(72)90360-X

[35] Hays, R.M., Levine, S.D., Myers, J.D., Heinemann, H.O., Kaplan, M.A., Frank, N. and Berliner, H. (1977) Urea transport in the dogfish kidney. Journal of Experimental Zoology, 199, 309-316. doi:10.1002/jez.1401990304

[36] Hyodo, S., Katoh, F., Kaneko, T. and Takei, Y. (2004) A facilitative urea transporter is localized in the renal collecting tubule of the dogfish Triakis scyllia. The Journal of Experimental Biology, 207, 347-356. doi:10.1242/jeb.00773

[37] Lacy, E.R. and Reale, E. (1985) The elasmobranch kidney. II. Sequence and structure of the nephrons. Anatomy and Embryology, 173, 163-186. doi:10.1007/BF00316299

[38] Lacy, E.R. and Reale, E. (1995) Functional morphology of the elasmobranch nephron and retention of urea. In: Wood, C.M. and Shuttleworth, T.J., Eds., Cellular and Molecular Approaches to Fish Ionic Regulation, Accademic Press, Inc., S. Diego, 107-137.

[39] Hentschel, H., Elger, M. and Schmidt-Nielsen, B. (1986) Chemical and morphological differences in the kidney zones of the elasmobranch, Raja erinacea. Comparative Biochemistry and Physiology A, 84, 553-557. doi:10.1016/0300-9629(86)90364-6

[40] Morgan, R.L., Wright, P.A. and Ballantyne, J.S. (2003) Urea transport in kidney brush-border membrane vesicles from an elasmobranch, Raja erinacea. The Journal of Experimental Biology, 206, 3293-3302. doi:10.1242/jeb.00555

[41] Morgan, R.L., Ballantyne, J.S. and Wright, P.A. (2003) Regulation of a renal urea transporter with reduced salinity in a marine elasmobranch, Raja erinacea. The Journal of Experimental Biology, 206, 3285-3292. doi:10.1242/jeb.00554

[42] Janech, M.G., Fitzgibbon, W.R., Nowak, M.W., Miller, D.H., Paul, R.V. and Ploth, D.W. (2006) Cloning and functional characterization of a second urea transporter from the kidney of the Atlantic stingray, Dasyatis sabina. American Journal of Physiology (Regulatory, Integrative and Comparative Physiology), 291, R844-R853. doi:10.1152/ajpregu.00739.2005 
[43] Douady, C.J., Dosay, M., Shivji, M.S. and Stanhope, M.J. (2003) Molecular phylogenetic evidence refuting the hypothesis of Batoidea (rays and skates) as derived sharks. Molecular Phylogenetic Evolution, 26, 215-221. doi:10.1016/S1055-7903(02)00333-0

[44] Janech, M.G., Fitzgibbon, W.R., Chen, R., Nowak, M.W., Miller, D.H., Paul, R.V. and Ploth, D.W. (2003) Molecular and functional characterization of a urea transporter from the kidney of the Atlantic stingray. American Journal of Physiology (Renal Physiology), 284, F996-F1005.

[45] Thorson, T.B. (1970). Freshwater stingrays, potamotrygon spp.: Failure to concentrate urea when exposed to saline medium. Life Sciences, 9, 893-900. doi:10.1016/0024-3205(70)90059-7

[46] Thorson, T.B. and Gerst, J.W. (1972) Comparison of some parameters of serum and uterine fluid of pregnant, viviparous sharks (Carcharhinus leucas) and serum of their near-term young. Comparative Biochemistry and Physiology A, 42, 33-40. doi:10.1016/0300-9629(72)90363-5

[47] Compagno, L.J.V. and Cook, S.F. (1995) The exploitation and conservation of freshwater elasmobranchs: Status of taxa and prospects for the future. Journal of Aquariculture and Aquatic Sciences, 7, 62-90.

[48] Schwartz, F.J. and Dahlberg, M.D. (1978) Biology and ecology of the Atlantic stingray, Dasyatis sabina (Pisces: Dasyatidae), in North Carolina and Georgia. Northeast Gulf Science, 2, 1-23.

[49] Johnson, M.R. and Snelson, F.F.J. (1996) Reproductive life history of the Atlantic stingray, Dasyatis sabina (Pisces, Dasyatidae), in the freshwater St. Johns River, Florida. Bulletin of Marine Science, 59, 74-88.

[50] De Vlaming, V.L. and Sage, M. (1973) Osmoregulation in the euryhaline elasmobranch, Dasyatis sabina. Comparative Biochemistry and Physiology A, 45, 31-44. doi:10.1016/0300-9629(73)90006-6

[51] Wong, T.M. and Chan, D.K.O. (1977) Physiological adjustments to dilution of the external medium in the Lip shark Hemiscyllium plagiosum (Bennett). Journal Experimental Zoology, 200, 85-96. doi:10.1002/jez.1402000111

[52] Cooper, R.A. and Morris, S. (1998) Osmotic and haematological response of the Port Jackson shark Heterodontus portusjacksoni and the common stingaree Trygonoptera testacea upon exposure to diluted sea water. Marine Biology (Berlin), 132, 28-42.

[53] Yamaguchi, Y., Takaki, S. and Hyodo, S. (2009) Subcellular distribution of urea transporter in the collecting tubule of shark kidney is dependent on environmental salinity. Journal of Experimental Zoology A, 311, 705-718. doi:10.1002/jez.558

[54] Klein, J.D., Frohlich, O., Blount, M.A., Martin, C.F., Smith, T.D. and Sands, J.M. (2006) Vasopressin increases plasma membrane accumulation of urea transporter UT-A1 in rat inner medullary collecting ducts. Journal of the American Society of Nephrology, 17, 2680-2686. doi:10.1681/ASN.2006030246

[55] Blount, M.A., Mistry, A.C., Fröhlich, O., Price, S.R., Chen, G., Sands, J.M. and Klein, J.D. (2008) Phosphory- lation of UT-A1 urea transporter at serines 486 and 499 is important for vasopressin-regulated activity and membrane accumulation. American Journal of Physiology, 295, F295-F299. doi:10.1152/ajprenal.00102.2008

[56] Hyodo, S., Tsukada, T. and Takei, Y. (2004) Neurohypophysial hormones of dogfish, Triakis scyllium: Structures and salinity dependent secretion. General and Comparative Endocrinology, 138, 97-104. doi:10.1016/j.ygcen.2004.05.009

[57] Hazon, N. and Henderson, I.W. (1984) Secretory dynamics of 1a-hydroxycorticosterone in the elasmobranch fish, Scyliorhinus canicula. Journal of Endocrinology, 103, 205-211. doi:10.1677/joe.0.1030205

[58] Tam, W.L., Wong, W.P., Loong, A.M., Hiong, K.C., Chew, F.S., Ballantyne, J.S. and Ip, Y.K. (2003) The osmotic response of the Asian freshwater stingray (Himantura signifer) to increased salinity: A comparison with marine (Taeniura lymma) and Amazonian freshwater (Potamotrygon motoro) stingrays. The Journal of Experimental Biology, 206, 2931-2940. doi:10.1242/jeb.00510

[59] Anderson, W.G., Good, J.P., Pillans, R.D., Hazon, N. and Franklin, C.E. (2005) Hepatic urea biosynthesis in the euryhaline elasmobranch carcharhinus leucas. Journal of Experimental Zoology A, 303A, 917-921. doi:10.1002/jez.a.199

[60] Thorson, T.B., Brooks, D.R. and Mayes, M.A. (1983) The evolution of freshwater adaptation in stingrays. National Geographic Research Report, 15, 663-694.

[61] Lovejoy, N.R. (1997) Stingrays, parasites, and neotropical biogeography: A closer look at Brooks et al.'s hypotheses concerning the origins of neotropical freshwater rays (Potamotrygonidae). Systematic Biology, 46, 218230. doi:10.1093/sysbio/46.1.218

[62] Thorson, T.B., Cowan, C.M. and Watson, D.E. (1967) Potamotrygon spp.: Elasmobranchs with low urea content. Science, 158, 375-377. doi:10.1126/science.158.3799.375

[63] Gerst, J.W. and Thorson, T.B. (1977) Effects of saline acclimation on plasma electrolytes, urea excretion, and hepatic urea biosynthesis in a freshwater stingray, Potamotrygon sp. Garman, 1877. Comparative Biochemistry and Physiology A, 56, 87-93. doi:10.1016/0300-9629(77)90446-7

[64] Ip, Y.K., Tam, W.L., Wong, W.P., Loong, A.M., Hiong, K.C., Ballantyne, J.S. and Chew, F.S. (2003) A comparison of the effects of environmental ammonia exposure on the Asian freshwater stingray Himantura signifer and the Amazonian freshwater stingray Potamotrygon motoro. The Journal of Experimental Biology, 206, 3625-3633. doi:10.1242/jeb.00612

[65] Wolff, S.D. and Balaban, R.S. (1990) Regulation of the predominant renal medullary organic solutes in vivo. Annual Review of Physiology, 52, 727-746. doi:10.1146/annurev.ph.52.030190.003455

[66] Frank, H.S. and Franks, F. (1968) Structural approach to the solvent power of water for hydrocarbons; urea as a structure breaker. Journal of Chemical Physics, 48, 47464757. doi:10.1063/1.1668057 
[67] Yang, L. and Gao, Y.Q. (2010) Effects of cosolvents on the hydration of carbon nanotubes. Journal of American Chemistry Society, 132, 842-848. doi:10.1021/ja9091825

[68] Tobi, D., Elber, R. and Thirumalai, D. (2003) The dominant interaction between peptide and urea is electrostatic in nature: A molecular dynamics simulation study. Biopolymers, 68, 359-369. doi:10.1002/bip.10290

[69] Das, P. and Zhou, R. (2010) Urea-induced drying of carbon nanotubes suggests existence of a dry globule-like transient state during chemical denaturation of proteins. Journal of Physical Chemistry B, 114, 5427-5430. doi:10.1021/jp911444q

[70] Zhou, R., Li, J., Hua, L., Yang, Z. and Berne, B.J. (2011) Comment on "urea-mediated protein denaturation: A consensus view". Journal of Physical Chemistry B, 115, 13231328. doi:10.1021/jp105160a

[71] Yancey, P.H. and Somero, G.N. (1979) Counteraction of urea destabilization of protein structure by methylamine osmoregulatory compounds of elasmobranch fishes. Biochemestry Journal, 183, 317-323.

[72] Yancey, P.H. and Somero, G.N. (1980) Methylamine osmoregulatory solutes of elasmobranch fishes counteract urea inhibition of enzymes. Journal of Experimental Zoology, 212, 205-213. doi:10.1002/jez.1402120207

[73] Nozaki, Y. and Tanford, C. (1963) The solubility of amino acids and related compounds in aqueous urea solutions. Journal of Biology Chemistry, 238, 4074-4081.

[74] Singh, R., Ali Dar, T., Ahmad, S., Moosavi-Movahedi, A. A. and Ahmad, F. (2008) A new method for determining the constant-pressure heat capacity change associated with the protein denaturation induced by guanidinium chloride (or urea). Biophysic Chemistry, 133, 81-89. doi:10.1016/j.bpc.2007.12.006

[75] Bolen, D.W. and Fisher, J.R. (1969) Kinetic properties of adenosine deaminase in mixed aqueous solvents. Biochemistry, 8, 4239-4246. doi:10.1021/bi00839a003

[76] Forster, R.P. and Goldstein, L. (1976) Intracellular osmoregulatory role of amino acids and urea in marine elasmobranchs. American Journal of Physiology, 230, 925931.

[77] Mashino, T. and Fridovich, I. (1987) Effects of urea and trimethylamine-N-oxide on enzyme activity and stability. Archives of Biochemistry and Biophyics, 258, 356-360. doi:10.1016/0003-9861(87)90355-9

[78] Yancey, P.H. (2005) Organic osmolytes as compatible, metabolic and counteracting cytoprotectants in high osmolarity and other stresses. The Journal of Experimental Biology, 208, 2819-2830. doi:10.1242/jeb.01730

[79] Withers, P., Hefter, G. and Pang, T.S. (1994) Role of Urea and Methylamines in Buoyancy of Elasmobranchs. The
Journal of Experimental Biology, 188, 175-189.

[80] Steele, S.L., Yancey, P.H. and Wright, P.A. (2005). The little skate Raja erinacea exhibits an extrahepatic ornithine urea cycle in the muscle and modulates nitrogen metabolism during low-salinity challenge. Physiological and Biochemical Zoology, 78, 216-226. doi:10.1086/427052

[81] Pillans, R.D., Good, J.P., Anderson, W.G., Hazon, N. and Franklin, C.E. (2005) Freshwater to seawater acclimation of juvenile bull sharks (Carcharhinus leucas): Plasma osmolytes and $\mathrm{Na}^{+} / \mathrm{K}^{+}$-ATPase activity in gill, rectal gland, kidney and intestine. Journal of Comparative Physiology B, 175, 37-44. doi:10.1007/s00360-004-0460-2

[82] Treberg, J.R., Speers-Roesch, B., Piermarini, P.M., Ip, Y.K., Ballantyne, J.S. and Driedzic, W.R. (2006). The accumulation of methylamine counteracting solutes in elasmobranchs with differing levels of urea: A comparison of marine and freshwater species. The Journal of Experimental Biology, 209, 860-870. doi:10.1242/jeb.02055

[83] Haubrich, D.R. and Gerber, N.H. (1981) Choline dehydrogenase: Assay, properties and inhibitors. Biochemical Pharmacology, 30, 2993-3000. doi:10.1016/0006-2952(81)90265-3

[84] Maker, J.R., Struempler, A. and Chaykin, S. (1963) A comparative study of trimethylamine- $\mathrm{N}$-oxide biosynthesis. Biochemistry et Biophysica Acta, 71, 58-64. doi:10.1016/0006-3002(63)90985-5

[85] Goldstein, L. (1967). Urea biosynthesis in elasmobranchs. In: Gilbert, P.W., Mathewson, R.F., Rall, D.P. and Baltimore, M.D., Eds., Sharks, Skates and Rays, Johns Hopkins Press, Baltimore.

[86] Goldstein, L. and Dewitt-Harley, S. (1973) Trimethylamine oxidase of nurse shark liver and its relation to mammalian mixed function amine oxidase. Comparative Biochemistry and Physiology B, 45, 895-903. doi:10.1016/0305-0491(73)90150-8

[87] Goldstein, L. and Funkenhouser, D. (1972) Biosynthesis of trimethylamine oxide in the nurse shark, Ginglymostoma cirratum. Comparative Biochemistry and Physiology A, 42, 51-57. doi:10.1016/0300-9629(72)90365-9

[88] Treberg, J.R. and Driedzic, W.R. (2006) Maintenance and accumulation of trimethylamine oxide by winter skate (Leucoraja ocellata): Reliance on low whole animal losses rather than synthesis. American Journal of Physiology, 291, R1790-R1798.

[89] Cohen, J.J., Krupp, M.A. and Chidsey, C.A. 3rd (1958) Renal conservation of trimethylamine oxide by the spiny dogfish, Squalus acanthias. American Journal of Physiology, 194, 229-235. 